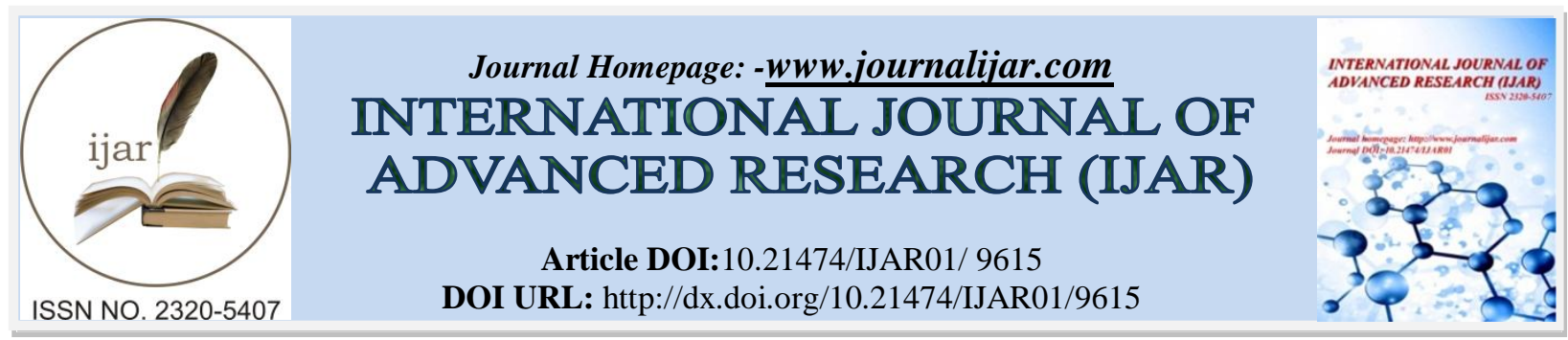

RESEARCH ARTICLE

\title{
THE FACTORS OF JOB SATISFACTION AND EMPLOYEE PERFORMANCE (CASE STUDY PT YICHENG LOGISTICS JAKARTA).
}

\author{
Adek, Agung Kwartama, Sumiyatiningsih, Didik Indriawan and Indah Sulita \\ Greater Jakarta National Maritime Academy.
}

\section{Manuscript Info}

Manuscript History

Received: 20 June 2019

Final Accepted: 22 July 2019

Published: August 2019

Key words:-

Salary, Social security, Work environment, Working relationship, Supervision, employee performance.

\begin{abstract}
This study aims to determine the factors of job satisfaction which consist of salary, social security, work environment, work relations and supervision both directly and simultaneously towards the commitment of employees of PT. Yicheng Logistics - Indonesia. This type of research uses a descriptive quantitative approach. The population of this study was the employee of PT. Yicheng Logistics - Indonesia. The total sample of 67 respondents taken by simple sampling technique. Data collection method use questionnaire. To find out how much the dependent variable effect on the independent variable was used multiple linear regression analysis. The result showed that salary (X1), social security (X2), work environment (X3), employment relationship (X4) and supervision (X5) simultaneously have a significant effect on employee performance (Y). While partially Salary (X1), Allowances (X2) and Work Environment (X3) there is no significant effect on employee performance (Y), except Work Relations (X4) and supervision (X5) have a significant effect on employee performance (Y).
\end{abstract}

Copy Right, IJAR, 2019,. All rights reserved.

\section{Introduction:-}

The era of the industrial revolution 4.0 brought about changes and developments in the organizational environment that had an impact on the demands and needs of an increasingly complex community. On the other hand changes and adjustments require employee morale and motivation in order to maintain job satisfaction and improve employee performance, so it be able to contribute to the achievement of organizational goals.

Changes and adjustment are issues that need to be dealt with immediately by human resources management in providing direction, coaching and motivating the workforce in an effort to improve employee performance against the goals and values of the organization, and a strong desire to use the effort in the interest of company (mowday et al, 1983)

The factors of satisfaction and dissatisfaction at work arising from PT Yicheng Logistics Jakarta employees in achieving company goals require supervision, work relationships and work environment that can create an ethically healthy climate because it is an effort to improve employee performance as a trigger to work better by paying attention to employee salaries (Batubara et al, 2013)

Corresponding Author:-Agung Kwartama.

Address:-Greater Jakarta National Maritime Academy. 
Martcahyo, et al (2012), said that employer organizations need to pay attention and implement the law of the republic of Indonesia regarding social security, this has a very significant effect on employee performance.

Based on the background of the problem, researchers are interested in conducting more in depth research and theoretical study of job satisfaction factors in the of salary, social security, work environment, work relationship and supervision that affect the performance of PT Yicheng logistics Jakarta employees.

\section{Formulating of the problem}

Based on the identification of the problem above, the researcher identifies how the influencing job satisfaction factor consist of salary, benefit, work environment, work relationship and supervision of work performance, both partially and simultaneously

\section{Purpose of the research}

The objectives to be achieved in this research are

1. analyze the existence of significant influence between salary, benefits, work environment, work relationships and supervision of work performance

2. analyze the existence of a significant influence between the factor of job satisfaction in the salary, benefits, work environment, work relationship and supervision simultaneously on work commitment

\section{Literatur Review Job satisfaction}

Each individual has a different level of job satisfaction in accordance with the system of values that apply to him. Mathis $(2010,248)$ said that job satisfaction is the emotional state of the employee where the meeting point occurs or does not occur between the value of employee work remuneration that is desired by the employee concerned, can be either financial or non financial wexley and yuki (2010) stated job satisfaction in an individual thing and the problem of job satisfaction can affect the level of employee absenteeism and turnover of the workforce, this means job satisfaction as on is feelings towards his job robins and judge (2002) said that things that can affect job satisfaction are divided into five factors namely :

1. salary

2. social security

3. work environment

4. working relationship

5. supervision

\section{Salary}

Dessler (2000) said that "salary is something related to money given to employees and the payment system based on the length of work". "Salary is one important element that can affect employee performance, because salary is a tool to meet various employee needs" (Hariandja and Marihot, 2002)

"Employee satisfaction that receives salaries in accordance with the payment system that is carried out fairly in accordance with the competence, expertise and work and in accordance with what is obtained and expectations, will trigger employees to be motivated to work harder and work performance to companies or employers who give wages" (Falianto, 2014)

Hanoman and Schwah (1985) said that "salary satisfaction is a multidimensional construct of satisfaction consisting of pay level, pay structure and social security administration, pay raise and benefit"

\section{Social Security}

Kertonegoro (1999) explained that "social security is a protection provided by the community for its members for certain events with the aim as far as possible to avoid the occurrence of these events which can result in the loss or decline of most of the income and to provide medical services of financial guarantees against the economic consequences of these events, as well as guarantees for family and child benefits".

Social security as an embodiment of social security for the system of protection and maintenance of social welfare for citizens organized by the government or society to maintain the level of social welfare, which is strengthened by the republic of Indonesia law number 40 of 2004 concerning the national social security system paragraph I states 
social security is a protection for workers in the form of compensation in the form of money in lieu of a portion of lost or reduced income and services as a result of events of conditions experienced by workers in the form of work accidents, illness, pregnancy, childbirth, and death (Asikin et al 2010)

The objectives of social security for employees, as follows:

1. Provide the level of welfare of employees so that they can carry out activities in the place of work within the family and community

2. Increase or at least maintain the ability to employee skills themselves

3. Provide an illustration for employees that they have a job that can guarantee life (Kertonegoro, 1999)

\section{Work environment}

According to Sedarmayanti (2014), work environment is all conditions that are around the workplace that will affect employees both directly and indirectly on their work then emphasized by Mangkunegara (2005) that the intended work environment includes clear job descriptions, challenging work targets, effective work communication patterns, work climate and relatively adequate work facilities. So the environment pleasant working climate can make employees feel at home in completing their work and the impact an employee job satisfaction and work performance and increasing productivity in order to achieve company goals.

Comfortable and conducive work environment companies need to pay attention to 1) physical work environment are all conditions that are around the work place, which include temperature, humidity, air circulation, lighting, noise, mechanical vibrations, odor, color, etc. 2) non physical work environment is all conditions that occur relating to work relationships, both relationships with colleagues, or relations with subordinates. Than the physical work environment is all physical conditions that are around the work place that can affect employees both directly and indirectly (Sedarmayanti, 2014)

\section{Working relationship}

Base on subsection 1 number 15 of law number 13 of 2003 concerning manpower, explains that the employment relationship is a relationship between employers and workers based on work agreement that have elements of work, wages and orders. So the employment relationship occurs because of an employment agreement between the employer and the worker. Employment agreements made in writing or verbally. Good working relationship and the attention of the leadership to subordinates, employees will feel that he is an important part of the company where he works to jointly achieve company goals. So work relationships can be interpreted as relationships that occur between individual parts or individuals both between them within the organization as a result of carrying out their respective duties and functions in achieving the goals and objectives of the organization (Kadarmo et al, 2001)

Soepomo (2003) said that employment relations occur after an employment agreement between the two parties, on one hand, workers are willing to work for a wage and the employer hires workers for a wage. So a working relationship between employees and the harmonious leadership is very important in increasing work productivity and having a positive mental attitude.

\section{Supervision}

According to Handayaningrat (2006), the purpose of supervision is to prevent or to correct mistakes, irregularities, discrepancies, deviations, and others that are not in accordance with the specified duties and authority the point is not to find fault with the person, but to find the truth of the results of the work.

Supervisors are needed to ensure that business operations can run without obstacles and encourage employees to be more responsible for their duties supervision activities by superiors will affect job satisfaction, therefore the process of observing the implementation of all company activities to ensure that all work being carried out can be in accordance with a predetermined plan (Siagian, 2012)

Supervision is a process to determine the standard of work to be carried out, assess it, and if necessary correct it with the intention that the work implementation is in accordance with the original plan (Manullang 2012). Stages of the supervision process are 1) setting standards and performance appraisal methods 2) job appraisal 3) comparing performance with work standards 4) thought corrective actions. 


\section{Research hypothesis}

Ho : job satisfaction factor variables consisting of salary, social security, work environment, work relationship and supervision partially have no significant effect on employee performance

Ha : Job satisfaction factor variables consisting of salary, social security, work environment, work relationship and supervision partially have a significant effect on employee performance

Ho : Job satisfaction factor variables consisting of salary, social security, work environment, work relationship and supervision simultaneously have no significant effect on employee commitment

$\mathrm{Ha} \quad$ : Job satisfaction factor variables consisting of salary, social security, work environment, work relationship and supervision simultaneously has a significant effect on employee commitment

\section{Methodology:-}

The object of this research is PT Yicheng Logistics Indonesia employees, a subsidiary of NOCC Yicheng logistics Tianjin China, located in the city of Jakarta. Aspects of employee performance and job satisfaction factors namely salary, social security, work environment, work relations, supervision population in this study are PT Yicheng Logistic Jakarta employees who are on Kayu Ramin street number 21, Utan Kayu Utara, Jakarta, Indonesia.

82 sample were distributed and 67 samples were used. The sampling technique used simple random sampling by ramdomly sampling PT Yicheng Logistics Jakarta employees. This research used descriptive quantitative, the aim is to provide or describe a situation or phenomenon that is happening now by using scientific procedures to answer the problem in actual primary data sources obtain from the results of distributing questionnaires and interviews with PT Yicheng Logistics Indonesia employees from October $1^{\text {st }}$ to October $31^{\text {st }}, 2018$, while secondary data in the form of study literature, websites, the internet and journals discuss salary, social security, work environment, work relationships, employee supervision and performance. The measurement of each variable uses a Likert scale with multiple linear analysis methods

\section{Result:-}

\section{Multiple linear regression test}

Multiple linier regression is an analysis measuring the magnitude of the influence between the independent variables of salary, job security, work environment, work relationship and supervisors with dependent statistical calculations can be seen in the unstandardized coefficients column in the coefficients table.

\begin{tabular}{|c|c|c|c|c|c|c|c|c|}
\hline \multicolumn{9}{|c|}{$\begin{array}{ll}\text { Coefficients }^{\mathbf{a}} & \\
\end{array}$} \\
\hline \multirow{2}{*}{\multicolumn{2}{|c|}{ Model }} & \multicolumn{2}{|c|}{$\begin{array}{l}\text { Unstandardized } \\
\text { Coefficients }\end{array}$} & \multirow{2}{*}{$\begin{array}{c}\text { Standardized } \\
\text { Coefficients } \\
\text { Beta }\end{array}$} & \multirow[t]{2}{*}{$\mathrm{t}$} & \multirow[t]{2}{*}{ Sig. } & \multicolumn{2}{|c|}{ Collinearity Statistics } \\
\hline & & B & Std. Error & & & & Tolerance & VIF \\
\hline \multirow[t]{6}{*}{1} & (Constant) & ,457 &, 345 & & 1,325 & , 190 & & \\
\hline & Salary & 100 & ,085 & ,114 & 1,174 & ,245 & ,573 & 1,747 \\
\hline & Assurance & ,021 & ,129 & ,026 &, 161 & ,873 & ,209 & 4,783 \\
\hline & Environment & ,084 & ,091 & ,092 & ,920 &, 361 &, 538 & 1,859 \\
\hline & Relationship & ,431 &, 129 &, 506 & 3,335 & ,001 & ,234 & 4,281 \\
\hline & Supervisor & ,231 & 9099 & ,229 & 2,338 & 023 & ,563 & 1,777 \\
\hline
\end{tabular}

Sources: processing data on 2018

As for the multiple regression equation as follows :

$\mathrm{Y}=0,457+0,1 \mathrm{X} 1+0,02 \mathrm{X} 2+0,084 \mathrm{X} 3+0,431 \mathrm{X} 4+0,231 \mathrm{X} 5$

\section{Explanation}

1. a constant value of 0.457 gives the sense that if salary (x1), work security (x2), work environment (x3), work relationship (x4), and supervisor (x5), simultaneously do not change or equal zero (0) then the amount of employee performance $(\mathrm{Y})$ is 0,457 units

2. The correlation coefficient of salary (X1), of 0,1 so a positive influence on the dependent variable (Y), meaning that each salary variable (X1) increases by 1 unit, than employee performance (Y) increases by 0,1 unit assuming other variables fixed or constant 
3. Correlation coefficient value of work security (X2) of 0,02 so a positive influence on the dependent variable (Y), meaning that each work security variable (X2) changes to 1 unit, then employee performance has increased by 0,02 unit assuming other variables fixed or constant

4. The value of the correlation coefficient of the work environment (X3) of 0,084 so positive influence on the dependent variable (Y), meaning that each work environment variable (X3), increase by 1 unit, than employee performance $(\mathrm{Y})$ increases by 0,084 units assuming other variables $t$ fixed or constant

5. The value of the correlation coefficient of work relations (X4) of 0,431 so a positive influence on the dependent variable (Y) means that each work relationship variable (X4) increases by 1 unit then employee performance $(\mathrm{Y})$ increases by $0,431.1$ unit assuming other variables are fixed or constant

6. The correlation coefficient value of supervisor (X5) is 0,231 so a positive effect on the dependent variable (Y), meaning that each supervisor variable (X5) increases by 1 unit, the employee performance (Y) increases by 0,231 units assuming the other variables are fixed or constant

\section{Heteroscedasticity test}

The purpose of the heteroscedasticity test is to test whether in regression model the variance of the residual inequality occurs for all observations in the linear regression model (Sekaran and Bougie, 2013). This can be seen in the table Heteroscedaticity

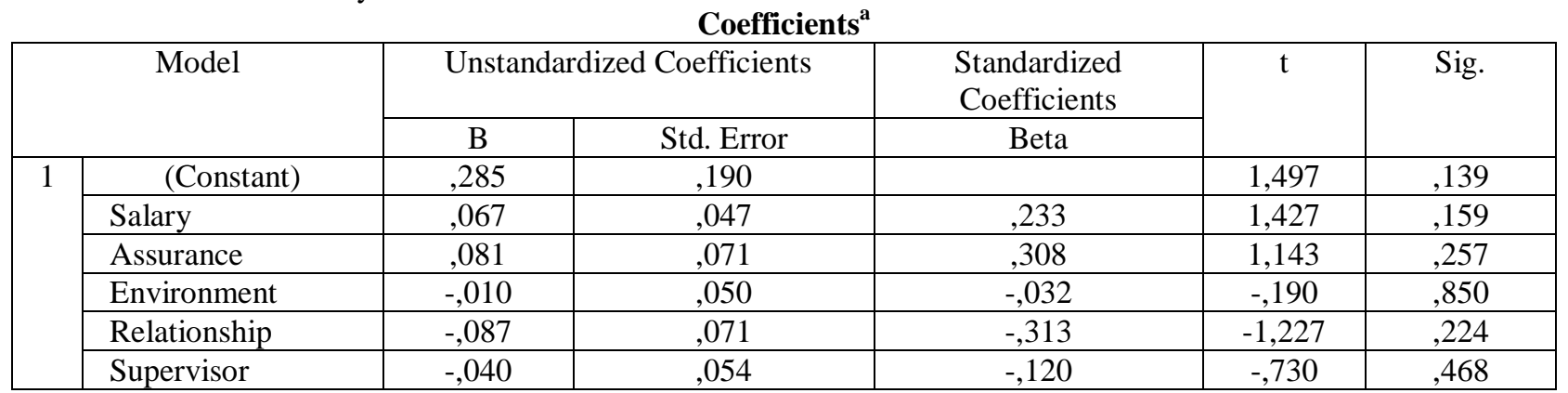

The results using the spearman Rho's test the significance value (sig) for the salary variable is 0,159 , the work guarantee is 0,257 , the work environment is 0,850 , the working relationship is 0,224 and supervisor is 0,468 greater that the absolute residual value of 0,05 . So it can be concluded that there is no problem with heteroscedasticity

\section{Multicollinearity test}

The purpose of the multicollinearity test is to test whether the regression variable is found to be a correlation between the independent variables (Sekaran and Bougie, 2013). This can be seen in the collinearity statistics column in the coefficients table. The result is a variable tolerance value of salary work security, work environment, work relationship and supervisors $>0,10$ while the VIF value of salary and supervisor variable $<10$. So it can be concluded that there are no multicollenearity variables between the independent variables in the regression model

\section{Hypothesis testing}

\section{t or partial test}

Based on the coefficient table above specifically colums $t$ and siy can be explained as follows :

1. Salary variable (X1) on employee performance $(\mathrm{Y})$, it is known that the value of $t$ count salary variable is 1,174 where $t$ count $(1,174)<t$-table $(1,999)$ and the significance of 0,245 is bigger than 0,05 . It means that there is no significant effect between the salary variable on employee performance variables

2. Work security variable (X2) on employee performance $(\mathrm{Y})$, it is known that the t-count of the employment guarantee variable is 0,161 where $\mathrm{t}$-count $(0,161)<\mathrm{t}$-table $(1,999)$ and the significance of 0,875 is bigger than 0,05 it means that there is no significant difference between the variable of work security and employee performance variable

3. Work environment variable (X3) on employee performance $(\mathrm{Y})$, it is known that the $\mathrm{t}$ count of the work environment variable is $0,920<\mathrm{t}$-table $(1,999)$ and the significance of 0,361 is smaller than 0,05 it means that there is no significant effect between work environment variables on employee performance variables

4. Work relationship variable (X4) to employee performance $(\mathrm{Y})$, it is known that the $\mathrm{t}$ count of the work relationship variable is 3,335 where to count $(3,335)>t$ - table $(1,999)$ and the significance of 0,001 is smaller 
than 0,05 . It means that there is a significant influence between the variables of work relationship on employee performance variables

5. Supervisor variable (X6) on employee performance (Y), it is known that the $\mathrm{t}$ count of the supervisor variable is 2,333 where $t$ count $(2,333)>t$ table $(1,999)$ and the significance of 0,23 is smaller than 0,05 . It means that there is a significant influence between the supervisor variables and the employee performance variables

\section{F test or simultaneous}

\begin{tabular}{|c|c|c|c|c|c|c|c|c|c|}
\hline \multicolumn{10}{|c|}{ Model summary } \\
\hline \multirow[t]{2}{*}{ Model } & \multirow[t]{2}{*}{$\mathrm{R}$} & \multirow{2}{*}{$\begin{array}{c}\mathrm{R} \\
\text { Square }\end{array}$} & \multirow{2}{*}{$\begin{array}{c}\text { Adjusted } \\
\text { R } \\
\text { Square }\end{array}$} & \multirow{2}{*}{$\begin{array}{c}\text { Std. } \\
\text { Error of } \\
\text { the } \\
\text { Estimate }\end{array}$} & \multicolumn{5}{|c|}{ Change Statistics } \\
\hline & & & & & $\begin{array}{c}\text { R } \\
\text { Square } \\
\text { Change }\end{array}$ & $\begin{array}{c}\mathrm{F} \\
\text { Change }\end{array}$ & df1 & df2 & $\begin{array}{c}\text { Sig. F } \\
\text { Change }\end{array}$ \\
\hline 1 &, $820^{\mathrm{a}}$ & ,672 & ,645 &, 42842 &, 672 & 24,991 & 5 & 61 &, 000 \\
\hline
\end{tabular}

a. Predictors: (Constant), Supervisor, Environment, Salary, Relationship, Assurance

Based on the table above, the use of F test simultaneous hypothesis testing, the results F count $(24,991)>$ F-table $(2,37)$ and a significance of 0,000 smaller 0,05 . So it can be concluded that the variables of work satisfaction factors, namely the variable salary social security, work environment, work relationships and supervision simultaneously have a significant effect on employee performance

\section{Discussion:-}

\section{Partial influence of work satisfaction factors on employee performance}

1. The effect of salary on employee performance Based on the results of hypothesis testing, it is known that salaries do not have a significant effect on employee performance, but the results of Hariandja and Maruhot's research (2002) stated that there is a significant effect between salary and employee performance. This can be related that the payroll system of PT Yicheng Logistic Jakarta is the base salary plus the frequency and intensity of the process and delivery of goods that are converted in the form of benefits, but some of the salary increases and benefits received by employees do not affect the performance of employees in efforts to corporate goals

2. The effect of social security on employee performanceThe result of previous studies Martcahyo et al (2002) stated that there is a significant influence between social security and employee performance, but based on the results of hypothesis testing, that social security has no significant effect on employee performance. This can be explained that every employee of PT Yicheng Logistic Jakarta includes a government program that is a health and employment social security agency (BPJS) but the BPJS is a program from the government. This does not have a significant effect on the level of employee welfare and the level of life of employees

3. The influence of the work environment on employee performanceThe results of the study of Maulana et al (2017), concluded that the work environment has a significant influence on employee performance. Furthermore Ardana (2001:208), also said that a safe and healthy work environment is proven to be inferior to the product. In addition, it was also stated that a pleasant work environment can include work places, and supporting facilities that accelerate the completion of work. Based on the hypothesis test, that the work environment does not have a significant influence on employee performance. It means the performance of employees who work in PT Yicheng Logistics Jakarta that engaged in freight forwarding services or documents very innovation, creativity and efforts to achieve targets in work and timely processing and completion of sending goods to customers, even though the physical and non physical environment is not supportive

4. The effect of work relationship on employee performance Based on the results of hypothesis testing, that work relationship have a very significant effect on employee performance and is supported by the results of the research of Sudira and Sudarman (2014) concluding that there is a significant effect between work relationship and work performance. Ajala (2012) said that work relations will have a good impact on employee performance romance positive mental attitude in a work relationship will affect the work atmosphere in achieving timely production targets and motivating employees for innovation and creativity in completing work, so as to provide good performance for the company

5. The influence of supervisors on employee performance Based on the results of hypothesis testing, it is known that supervision has a significant effect on employee performance, it can be accepted if seen from the results of Sasmita and Wasnury's research (2015) concluded that supervision has a significant effect on employee performance. This can be related to the supervisory function, namely supervision that has supervisory competence in accordance with the duties and regulations governing the supervisory function that is able to 
provide supervision from the level of executor to the level of the company leader by paying attention and complying with work standards and assessment methods in an effort to achieve the target of timely completion of the work it is necessary to minimize errors in work operation, both from the findings of supervisors and deviation of work standards necessary corrective action as clearly as possible so as not to hamper work that impacts on service, finance and company prestige.

\section{The simultaneous influence of work satisfaction factors on employee performance}

Based on the results of the multiple regression equation obtained $\mathrm{Y}=0,457+0,1 \mathrm{X} 1+0,02 \mathrm{X} 2+0,084 \mathrm{X} 3+0,431$ $\mathrm{X} 4+0,231 \mathrm{X} 5$, meaning that the contribution of salary variable (X1) is 0,1 and the employment guarantee variable (X2) is 0,02 , the work environment variable (X3) of 0,084 , the variable work relationship $(\mathrm{X} 4)$ of 0,431 , the supervisory variable (X5) of 0,231 for its increase in the value of employee performance.

All the result of the F test with a correlation value $(\mathrm{R})$ of 0,82 showed the relationship between variables of salary, work security, work environment, work relationship and supervision together have a significant effect on employee performance. While the coefficient of determination or R-square is 0,67 or $67 \%$, this shows that the product display and product quality influence the purchase decision of $67 \%$, while the rest of $100 \%-67 \%=33 \%$ is the influence of other valuable that are nor researched.

Employee performance outlined the innovation and creativity in achieving targets and on time in completing work in kept to minimum. This is influence by 1) the income received by employees in the form of salary, 2) the existence of social security to improve the welfare of employees so that they can carry out activities at their place of work, within the family and in the community .3) the creation of comfortable and conducive work environment, both in terms of physical and non physical environment. 4) besides that it is also influence by the working relationship between employees and the harmonious leadership which is very important in increasing work productivity and having a positive mental attitude. 5) supervise the implementation of work in accordance with the original plan, starting from the process of setting standard and methods of performance appraisal, to comparing performance with work standards, and taking corrective actions as early as possible as a solution to the problem.

\section{Conclusions and suggestion:- \\ Conclusions}

F test results with the coefficient or R-square value of 0,67 or $67 \%$, this shows that product display and product quality influence on purchasing decisions by $67 \%$, while the rest of $100 \%-67 \%=33 \%$ is the influence other variables not examined.

Partially, which does not have a significant influence, as follows:

1. The hypothesis test $t$-count $(1,174)<t$ table $(1,999)$ and the significance $0,245>0,050$. It means that part of the increase in salary and benefits received by employees does not affect employee performance in the company's goal efforts because the payroll system is the basic salary plus the frequency and intensity of the shipping process

2. Social security variables on employee performance, where the results of the hypothesis test $t$ count $(0,161)<t$ table $(0,999)$ and significance $0,873>0,050$. It means that some of social security received by employees does not affect employee performance in efforts to corporate goals due to procurement social security in the form of health and labor (BPJS) is a government program

3. Work environment variables on employee performance, where t count $(0,920)<\mathrm{t}$-table $(1,999)$ and significance $0,361>0,050$. It means the performance of employees who work in PT Yicheng Logistic Jakarta that engage in freight forwarding services or documents very innovation, creativity and efforts to achieve targets in completing works, and timely processing and completion of sending goods to consumers even thought the physical and non physical.

\section{Partially which have significant influences are :}

Variable work relationship with the employee performance where t count $(3,335)>t$ table $(1,999)$ and significance $0,001>0,050$. It means work relations will have a good impact on employee performance. Where a positive mental attitude in a work relationship will affect the work atmosphere in achieving timely production target and motivating employees for innovation and creativity in completing work, so as to provide good performance for the company Supervision variable on employee performance where t-count $(2,3381) \mathrm{t}$ table $(1,999)$ and significance $0,023>$ 0,050. This means that supervision is needed to improve employee performance by minimizing errors in work 
operations, both from the findings of supervisors and deviations of work standards necessary corrective action as early as possible so as not to hamper work that impacts on service, finance and company prestige

Simultaneously variable salary work security, work relationship, supervisors significant effect on employee performance, where the hypothesis test results are F count $(24,991) \mathrm{F}$ table $(2,37)$ and significance $0,00<0,50$

\section{Suggestion}

Things that need to be considered to improve the performance of PT Yicheng Logistics Jakarta employees as follows:

1. Periodic salary increases based on merit, in addition to regional minimum wage as income received by employees

2. Periodic employee health checks financed by the company, in addition to employee being member of the health and employment social security.

3. Periodically companies holding mutual cooperation within the company environment, especially on environment days

4. Good working relationship need to be maintained and improved by involving employees in human resource bound exercise

5. Periodic training related to the inherent supervision of each work environment or between departments as a form of ownership company

\section{Bibliography:-}

1. Undang Undang Republik Indonesia Nomor 13 tahun 2003 tentang Ketenagakerjaan

2. Ajala, immanuel Majekodunmi. 2012. The Influence Of Workplace Environment On Workers, Welfare, Performance and Productivity. The African Symposium. Vol, 12. No, 1. Hal. 145.

3. Ardana, I Komang; Ni Wayah Mujiati dan Iwayan Mudiartha Utama. 2012. Manajemen Sumber Daya Manusia. Yogyakarta: Graha Ilmu

4. Asikin, H. Zainal, et al., 2010, Dasar-Dasar Hukum Perburuhan. Edisi.8. Jakarta: PT RajaGrafindoPersada..

5. Batubara, Khairunnisa; Sugiharto Pujangkoro dan Buchari. 2013. Pengaruh Gaji, upah dan Tujnjangan Karyawan terhadap kinerja karyawan pada PT XYZ. e-Jurnal Teknik Industri FT USU .Vol 3, No. 5, Hal. 2328.

6. Dessler, G. 2000. Manajemen Personalia. Edisi 3. Terjemahan Agus Dharma. Jakarta: Erlangga

7. Falianto, 2014. Pengaruh kepuasan gaji, Shift Kerja malam dan kepuasan kerja terhadap intensi keluar Karyawan. Jurnal Ilmu Manajemen, Vol. 11, No 2.

8. Guritno, Bambang dan Waridin. 2005. "Pengaruh Persepsi Karyawan Mengenai Perilaku Kepemimpinan, Kepuasan Kerja dan Motivasi Terhadap Kinerja”. JRBI, Vol.1 No. 1, Hal.63-74.

9. Handayaningrat, Soewarno 2006, Pengantar Studi Ilmu Administrasi dan Manajemen, Jakarta: Gunung Agung

10. Hariandja, Efendi dan Tuo, Marihot. 2002. Manajemen Sumber daya Manusia. Jakarta : Pusaka Widyatama.

11. Heneman, H.G. III \& Schwab, D.P. 1985. Pay satisfaction: Its multidimensional nature and measurement. International Journal of Psychology. Vol.20. Hal 129-141.

12. Mangkunegara, Anwar Prabu 2015. Sumber Daya Manusia Perusahaan. Cetakan kedua belas. Remaja Rosdakarya:Bandung

13. Manullang, M .2012. Manajemen Sumber Daya Manusia. Ghalia Indonesia. Jakarta.

14. Moulana, Ferry;. Bambang swasto Sunuhargo dan Hamidah Nayati Utami. 2017. Pengaruh lingkungan Kerja terhadap kinerja melaui variabel mediator Motivasi kerja, Jurnal Administrasi Bisnis (JAB). Vol. 44 No.1.

15. Kadarmo, Siwi Ultima; Nies Daan Suganda dan Supono, 2001, Koordinasi dan Hubungan Kerja, Lembaga Administrasi Negara-Republik Indonesia, Jakarta .

16. Kertonegoro Sentanoe, 1999, Hubungan Industrial, Hubungan Antara Pengusaha Dan Pekerja (Bipartid) Dan Pemerintah (Tripatid), Jakarta, Yayasan Tenaga Kerja Indonesia

17. Martcahyo, Vendy Aries; Wahyu Hidayat dan Sri Suryoko. 2012. Pengaruh Pelatihan kerja, Jaminan sosial dan insentif terhadap Kinerja Karyawan Bagian Produksi PT Furima Semarang, Junarl Ilmu Administrasi Bisnis Vol.1 No.1 Hal 1-16

18. Mathis, L Robert 2010. Strategic Human Resources Management. Edition 13, Southwestern: Chengange Learning.

19. Mowday, R. T., R. M. Steers and I. W. Porter. (1983).“The Measurement of Organizational Commitment”. Journal of Applied Psychology. Vol.84, Hal.408-414. 
20. Sasmita, Jumiati dan Rendra Wasnury. 2015. Pengaruh Pengawasan dan lingkungan kerja terhadap kinerja karyawan bagian pemasaran PT. Indofoor Sukses Makmur. Jurnal JOM FEKON Universitas Riau. Vol.2 No.1. Hal 1-12.

21. Sekaran, Uma dan Bougie Roger, 2013. Research Methods For Business:A Skill-Building Approach. Sixth Edition, United Kingdom: John Wiley \& Sons Ltd.

22. Sedarmayanti. 2014. Sumber Daya Manusia dan Produktivitas Kerja. Jakarta: Mandar Maju

23. Siagian, Sondang P. 2012. Kiat Meningkatkan Produktivitas Kerja. Jakarta: PT. Rineka Cipta

24. Soepomo, Imam 2003. Pengantar Hukum Perburuhan, Edisi Revisi 2003, Djambatan, Jakarta

25. Sudira, Putu Gde Edy Novayana dan Nyoman sudarma. 2014. Pengaruh Hubungan Kerja, Komunikasi dan Tingkat kesejahteraan terhadap Kinerja Karyawan pada Perusahaan PT. BPR Sari Dananiaga Tabanan, E_jurnal Manajemen Universitas Udayana. Vol.3 No.5

26. Robbins, Stephen, P dan Judge, Thimoty.A. 2016. "Perilaku Organisasi". Edisi 16 Jakarta: Salemba 4.

27. Wexley, K.W, dan Yukl, Gray A, 2010 Organizational behavior and personnel psychology, Homewood Illionis richard D.Irwin. 